\title{
The Four Levels of Awakening
}

\author{
Bhikkhu Anālayo ${ }^{1}$ (D)
}

Accepted: 16 October 2020 / Published online: 10 November 2020

(C) The Author(s) 2020, corrected publication 2021

\begin{abstract}
The early discourses present the realization of four levels of awakening as the chief purpose of mindfulness practice. A survey of the opinions of various scholars, alleging these four levels to be a later development, shows that the main arguments proposed in support of this assessment are unconvincing. The testimony provided by a comparative study of the early discourses instead conveys the impression that these four levels of awakening are an integral part of the teachings of early Buddhism in the form in which they have been preserved in the textual records. These four levels depict a gradual purification of the mind which can be achieved through the cultivation of insight based on the practice of mindfulness.
\end{abstract}

Keywords Arahant $\cdot$ Awakening $\cdot$ bodhi $\cdot$ Enlightenment $\cdot$ Four fruits $\cdot$ Four paths $\cdot$ Once-return $\cdot$ Nirvana $\cdot$ Non-return $\cdot$ Stream-entry

In early Buddhist thought, the chief function of mindfulness practice is to lead to awakening (Anālayo 2021). The early discourses regularly depict four main levels of awakening. Based on a first introduction to these four levels provided to the readership of this journal by Amaro (2019), the present article intends to offer a closer survey of these four levels, in particular in critical dialogue with selected suggestions made by various scholars in relation to them. Throughout this exploration, the issue at stake is to arrive at an accurate reflection of what the textual records of early Buddhist thought convey about these levels of awakening.

\section{Awakening or Enlightenment?}

The Indic term bodhi, here translated as "awakening," is often alternatively rendered as "enlightenment." Cohen (2006, p. 3) explained that already by "the mid-1870s, it had become commonplace to call the buddha 'enlightened.' By the end of the 1880 s, the terminologies of

Bhikkhu Anālayo

1 Barre Center for Buddhist Studies, 149 Lockwood Road, Barre, MA 01005, USA 'enlightened' and 'enlightenment' dominated the English-language literature on Buddhism." McMahan (2008, p. 18) reasoned that the term bodhi

literally means "awakening" and describes the Buddha's highest attainment under the bodhi tree. The most common English translation, "enlightenment," invokes, however, a complex of meanings tied to the ideas, values, and sensibilities of the European Enlightenment: reason, empirical observation, suspicion of authority, freedom of thought, and so on. Early translators, moreover, consciously forged this link. Buddhist studies pioneer Thomas W. Rhys Davids (1843-1922) ... translated bodhi as "Enlightenment" and explicitly compared the Buddha with the philosophers of the European Enlightenment.

In an encyclopedia entry on the term bodhi, Gimello (2004, p. 50) offered the following assessment:

Those who are attentive to the more literal meaning of the Indic original tend to translate bodhi in English as "awakening," and this is to be recommended. However, it has long been conventional to translate it as "enlightenment," despite the risks of multiple misrepresentation attendant upon the use of so heavily freighted an English word. 
Norman (1990, p. 26) explained:

The translation "enlightenment" is normally reserved for bodhi or sambodhi, but it is somewhat misleading in that the root budh- which underlies these words has no direct connection with "light." The root means literally "to wake up," or metaphorically "to wake up (to a fact), to know it," and "awakening" would be a more literal translation of bodhi. The past participle buddha is used actively to mean "one who has awakened, one who has gained knowledge."

An example illustrating the basic sense of the root budh in a context not related to any higher attainment can be found in a description of someone who has various experience during a dream, all of which vanish as soon as the person wakes up:

On waking up, one would not see any of it.

(MN 54: so pațibuddho na kiñci passeyya).

If one has woken up, one sees none of it all.

(MĀ 203: 彼若悟已, 都不見一).

The Pāli term pațibuddha used here (just as its Chinese counterpart 悟) conveniently exemplifies the nuances that derivatives of the root budh would have carried in the ancient setting (Anālayo 2011, p. xxiii; see also Anālayo 2013). In sum, the term bodhi is best rendered as "awakening," rather than employing a term that "evokes discourses associated with eighteenth century Europe's aspirations towards an age of reason" (Cohen 2010, p. 101).

\section{The Buddha as a Cowherd}

In the ancient Indian context, the employment of the image of a cowherd in a religious context naturally calls up Kṛșna (Vaudeville 1975). However, the early Buddhist discourses also present the Buddha in the role of a cowherd, and one such case relates to the theme of the four levels of awakening. The discourse in question describes how a wise cowherd will lead cattle across the river Ganges in such a way that not only the strong bulls but also the weaker cows and even the young calves get across safely. The different types of cattle taken across the river illustrate Buddhist disciples who reach different levels of awakening. Those comparable to strong bulls are as follows:

[In the same way are] those monastics who are arahants, with influxes destroyed, who have reached perfection, done what had to be done, laid down the burden, attained their own goal, with the fetter of becoming destroyed, and who are liberated by right and penetrative knowledge.

(MN 34: ye te bhikkhū arahanto khīnāsavā vusitavanto katakaran̄īya ohitabhārā anuppattasadatthā parikkhīnabhavasamyojanā sammadañ̃̄ā vimuttā).

In the same way, with the influx-free liberation of the mind and liberation by wisdom my disciples are able to destroy the influxes, here and now personally knowing and realizing: "Birth for me has been eradicated, the holy life has been established, what had to be done has been done, I myself know that there will be no acquiring of further existence."

(SĀ 1248: 如是我聲聞能盡諸漏, 無漏心解脫, 慧解脫, 現法 自知作證: 我生已盡, 梵行已立, 所作已作, 自知不受後有; the original abbreviates and has been supplemented from $S \bar{A} 110$ ).

My disciples are again also like that: their influxes are destroyed by accomplishing the influx-free liberation of the mind and liberation by wisdom, here and now personally realizing it and themselves dwelling in it. ( EĀ 43.6: 我弟子亦復如是, 盡有漏, 成無漏心解脫, 智慧解 脫, 於現法中以身作證而自遊化).

The three parallels agree in qualifying arahants, those who have reached the highest of the four levels of awakening, as having destroyed the influxes (assaval áśrava/漏/zag pa). In the early discourses these influxes are usually listed as three, comprising the influxes of sensuality, of becoming, and of ignorance (Anālayo 2012). The next level of awakening, corresponding to cattle that are weaker than the strong bulls, finds the following description:

[In the same way are] those monastics who, with the eradication of the five lower fetters, will be of spontaneous appearance and attain final Nirvana there, not being subject to returning from that world.

(MN 34: ye te bhikkhū pañcannam orambhāgiyānam samyojanānam parikkhayā opapātikā tattha parinibbāyino anāvattidhammā tasmā lokā).

In the same way, with the eradication of the five lower fetters my disciples attain non-return and will experience birth there, without returning to this world.

(SĀ 1248: 如是我諸聲聞斷五下分結, 得阿那含, 於彼受生, 不還此世).

My disciples are again also like that: by eradicating the five lower fetters they accomplish nonreturn and will attain final Nirvana there, without returning here. 
(EĀ 43.6: 我聲聞亦復如是, 斷五下結, 成阿那含, 於彼般涅 槃, 不還來此間).

The parallels agree in mentioning the five lower fetters (samyojana), which are elsewhere listed as comprising the fetters of identity belief, doubt, clinging to (specific) moral behaviors and observances (as in themselves leading to liberation), sensual lust, and ill will. The three versions also allude, in complementary ways, to the type of rebirth to be expected of nonreturners. These are so called because they will not return to be born in this human world and instead be reborn only in a particularly elevated celestial realm. The next level of awakening, corresponding to still weaker cattle, finds depiction as follows:

[In the same way are] those monastics who, with the destruction of the three fetters and the weakening of lust, anger, and delusion, are once-returners; coming once to this world they will make an end of dukkha.

(MN 34: ye te bhikkhü tinnạm samyojanānam parikkhayā rāgadosamohānam tanuttā sakadāgāmino sakideva imam lokam āgantvā dukkhass' antam karissanti).

In the same way, with the eradication of the three fetters and the weakening of lust, ill will, and delusion my disciples attain once-return; coming once to this world they will [gain] the final transcendence of dukkha. (SA 1248: 如是我聲聞斷三結, 食, 恚, 瘯薄, 得斯陀含, 一來 此世, 究竟苦邊).

My disciples are again also like that: with the eradication of the three underlying fetters and the weakening of sensual lust, anger, and delusion they accomplish once-return; coming once to this world they will completely make an end of dukkha.

( $E \bar{A}$ 43.6: 我弟子亦復如是, 斷三結使, 娞, 怒, 璇薄, 成斯陀 含, 來至此世, 盡於苦際).

The reference in the parallels to three fetters intends the first three in the list of five given above (personality belief, doubt, and clinging to moral behaviors and observances). The oncereturner will experience only one more rebirth, differing from the non-returner insofar as this can take place in the human world. The lowest of the four stages of awakening is explained in this way:

[In the same way are] those monastics who, with the destruction of the three fetters are stream-enterers, having a fixed destiny and being bound to full awakening without [ever] being subject to perdition.

(MN 34: ye te bhikkhū tinnạm samyojanānam parikkhayā sotāpannā avinipātadhammā niyatā sambodhiparāyanā).
In the same way, with the eradication of the three fetters my disciples attain stream-entry, are certain of rightly progressing toward full awakening without falling into a bad destiny and will [gain] the final transcendence of dukkha within seven rebirths among humans and celestials.

(SĀ 1248: 如是我聲聞斷三結, 得須陀洹, 不隋惡趣, 決定正 向三菩提, 七有天人往生, 究竟苦邊).

My disciples are again also like that: with the eradication of the three underlying fetters they accomplish streamentry, being certain of obtaining the crossing over. ( EĀ 43.6: 我弟子亦復如是, 斷三結使, 成須陀洹, 必至得度; the reference to $三$ is based on adopting a variant reading).

The parallel versions agree that stream-enterers have eradicated the three fetters and are destined to reach full awakening. Further indications not mentioned explicitly in all versions are that stream-enterers will reach the final goal within up to seven more rebirths, having won the assurance that none of these will take place in any of the lower realms of existence recognized in ancient Indian cosmology.

The chief point that emerges from the material common to the parallel versions on the topic of the four levels of awakening is an overall concern with the eradication or destruction of defilements, expressed in terms of fetters and influxes. In the traditional setting, mindfulness practice was aimed at completely overcoming all these mental negativities (rather than just learning to be at ease with one's negative emotions). The centrality of purification of the mind receives a complementary highlight in another discourse (MN 40 and MĀ 183), according to which monastic disciples of the Buddha must dedicate themselves to purifying their minds to deserve the very appellation "recluse."

Another noteworthy element in the above descriptions is the degree to which these four levels of awakening are interrelated with the notion of rebirth (Anālayo 2018). In fact, two of the four levels take their appellation from this notion, as the non-returner and the once-returner are so-called precisely because of the type of rebirth that awaits them. This does not imply that the early Buddhist teaching on purification of the mind is confined to the context of rebirth. It does mean, however, that the idea of rebirth has to be taken into account in order to understand properly the implications of awakening in early Buddhist thought.

\section{The Four Levels of Awakening}

According to some scholars, some of the four levels of awakening are later additions to the teachings of early Buddhism. Before examining a selection of relevant arguments, it needs 
to be noted that a proper appreciation of "early Buddhism" requires a comparative study of the different parallel versions of a particular discourse, in the manner exemplified above. In keeping with proper scientific procedure, a survey of all relevant data is needed before developing interpretations and drawing conclusions on the nature of early Buddhist doctrine. Exclusive reliance on Pāli texts can for this reason only provide a basis for conclusions confined to the Pāli tradition on a particular issue, simply because such a procedure neglects to take into account the substantial body of evidence for early Buddhist thought preserved in non-Pāli texts.

Moreover, the early discourses show the Buddha to have had a clear awareness of the limitations of language, allowing for a flexible use of different complementary terms to express the same meaning. A case in point is a discourse which lists various terms that could be used to refer to the begging bowl of a monastic, encouraging the audience not to insist on one particular term as the only right one (Anālayo 2011, p. 796). It is only in later exegesis that doctrinal terminology comes to be more tightly defined and streamlined. Hence, lack of streamlining of terminology also does not warrant being considered as problematic in itself, making it commendable to beware of overly literal readings of a particular expression or phrase.

A third point to be taken into account is that the early discourses are records of individual oral teachings whose content and manner of exposition stood in close dialogue with the type of audience and setting within which a particular exposition was given. Each discourse is contextual and needs to be evaluated accordingly. This differs from later exegesis, which shows a growing concern with comprehensive coverage of a particular topic (Anālayo 2014). For this reason, the expectation that each discourse should treat a particular topic or issue in a thoroughly comprehensive manner, failing which there must be a substantial doctrinal problem, is based on a category mistake.

Based on these preliminary considerations, the first argument to be examined here relates to the expectation of finding already in the early discourses the type of comprehensive coverage provided in later exegesis. Horner (1934, p. 788) considered the idea of four levels of awakening to be a later development, based on noting that the

omission of the four Ways from among the Fours of the Sarigiti Suttanta ... suggests that at the time when this Suttanta was written down the Four Ways had not been established as a group.

The reasoning is unexpected, as she herself (p. 787) noted that the Sangiti-sutta covers the four fruits of recluseship, which are the fruits of stream-entry, of once-return, of nonreturn, and of arahantship (DN 33: cattāri sāmaññaphalāni: sotāpattiphalam, sakadāgāmiphalaṃ, anāgāmiphalam, arahattaphalam). It could be added that the presentation in the Sangiti-sutta receives support from its parallels, which list the same four (Stache-Rosen 1968, p. 98 (reconstructed): catvāri śrāmanyaphalāni: ... śrotaāpattiphalam sakrdāgāmiphalam anāgāmiphalam agraphalam arhatvam, DĀ 9: 四沙門果: 須陀洹果, 斯陀含果, 阿那含果, 阿羅漢果, and $\mathrm{T}$ 12: 四沙門果: .... 謂須陀洹果, 斯陀含果, 阿那含果, 阿羅漢果). Since these four fruits are to be attained by the corresponding four ways (or paths), once the four fruits are mentioned explicitly in the different versions of this discourse, there is hardly any room left to problematize the absence of an additional reference to the corresponding group of four ways.

Horner (p. 791) also saw a problem with the third level of awakening in relation to full awakening, reasoning that it is

not easy to reconcile to this concept [of full awakening] the concept of the Way of No-return as a stage on the way to this same arahanship. For if, after a person has left this earth, he is not to return to it, if he is to pass utterly away in the realm where he is reborn after his bodily death here, how can he become an arahan as this is ordinarily conceived by the texts, with their insistence on ditthe va dhamme (here and now, lit.:, in these very seen conditions)? ... the gulf between the non-returner and the arahan is physically unbridgeable, and therefore the inclusion of the third Way is out of place if it is thought that the attainment of arahanship here and now is the ideal of those on the Way of No-return.

The qualification of arahant-ship as being attained "here and now" applies to those who reached full awakening in the same lifetime in which they came into contact with the Buddha's teaching. It does not follow that those who reached lower levels of awakening or even none could not progress to full awakening in a subsequent life. In fact, one of the possible solutions proposed by Horner (p. 791) to resolve the perceived problem is that, in the case of those progressing beyond lower levels of awakening in a subsequent life, "the arahanship thus thought of did not fulfil the 'here and now' condition." Although this suggestion would indeed settle the issue, the same alledged problem has been pursued further by Manné (1995, p. 94):

The stage anāgāmin [non-returner] contradicts the basic Buddhist teaching that Enlightenment is attainable in the present lifetime. This discrepancy shows that this stage was invented later, and most likely after the time of the Buddha. The same must be said about the stage of sakadāgāmin [once-returner] which is so minimally developed in the texts. The close comparison between the etymological structure of these two terms suggests that they came into being together to serve the same purpose ... Originally, then, at the time of the Buddha, there 
were converts, and Arahats - practitioners who had attained Liberation. The invention of the stages of anāgāmin, and sakadāgāmin, however, necessitated the elaboration of the state of being a convert into the stage of sotāpanna [stream-enterer].

The attainability of full awakening in the present life does not imply that every single Buddhist disciple must reach the final goal in the same lifetime in which a first exposure to Buddhist teachings took place. Another occurrence of the phrase "here and now" concerns the fruition of karma, which can take place either in this life or else on a later occasion (AN 10.208: ditthe va dhamme upapajjam vā apare vā pariyāye). The parallels agree in considering such ripening in the present life to be just an alternative possibility (MĀ 15: 或現世受, 或後 世受 and Up 4081: mthong ba'i chos nyid la dang, skyes nas dang, lan grangs gzhan na myong bar 'gyur $b a^{\prime} o$ ). The main difference between the parallels is that the Chinese version just refers to a later life in general as a single alternative, whereas the Pāli and Tibetan discourses distinguish two alternatives, which are either the next life or a later time.

The same sense of the phrase "here and now" (ditthe va dhamme and its counterparts 現世 and mthong ba'i chos) holds for full awakening, whose attainment in this life is just one possibility and not the only one. It can also be attained in the next life (namely by once-returners and non-returners) or at a later time (namely by stream-enterers). It is only by relying on an unwarranted literal reading of the phrase that this fairly straightforward situation becomes obscured.

Manné (p. 112) further reasoned that a discourse in the Anguttara-nikaya served to authenticate the four levels of awakening "by attributing the Buddha with the fruits of each of these stages, thus making them a part of his personal history," so that in this discourse "the Buddha is attributed with each of these fruits" (p. 88). The relevant Pāli passage in the Anguttara-nikāya proceeds in this way:

Monastics, with the manifestation of one person, of the thus-gone one, the arahant, the fully awakened one ... there is the realization of the fruit of knowledge and liberation, the realization of the fruit of stream-entry, the realization of the fruit of once-return, the realization of the fruit of non-return, and the realization of the fruit of arahant-ship.

(AN 1.13.6: tathāgatassa arahato sammāsambuddhassa, imassa kho, bhikkhave, ekapuggalassa pātubhāvā ... vijjāvimuttiphalasacchikiriyā hoti, sotāpattiphalasacchikiriyā hoti, sakadāgāmiphalasacchikiriyā hoti, a nāgāmiphalasacchikiriy $\bar{a}$ hot $i$, arahattaphalasacchikiriya hoti).
This passage does not attribute the attainment of each of the four levels of awakening to the Buddha. Instead, the point of the passage is that the coming into existence of a Buddha, here referred to as the manifestation of a thus-gone one (tathägata), makes it possible that these four levels can be attained by others. One needs a Buddha as one's teacher to be able to realize these four fruits. This type of presentation is fairly common in the early discourses, in that certain teachings only become available once a Buddha has manifested in the world. Another example of this type presents the factors of the eightfold path as something that only arises when a Buddha has arisen (SN 45.16, see also SĀ 766).

Based on relating the Pāli version of this passage (SN 45.16) to the indication that only a Buddha can arouse the unaroused path (SN 22.58, see also SĀ 75), Masefield (1986/1987, p. 141) reasoned that this is "no doubt, to be understood in the sense of causing the path to arise to a specific person at a given time." According to his assessment, this then implies that, after the passing away of the Buddha, it is no longer possible to reach any of the four levels of awakening, since "the Buddha alone can establish persons on the supramundane path." This reasoning also misunderstands the import of Pâli passages like the one translated above. A continuity of the possibility of attaining a level of awakening does not need the Buddha to remain alive; it only requires his teachings to be still accessible.

Another argument based on the expectation of finding a comprehensive coverage was proposed by Pande (1957, p. 539), who argued for the lateness of the four levels of awakening since "had the theory of the Maggas [four paths] and the corresponding Phalas [four fruits] been early, we might have expected some reference to them in the Sāmaññaphala." Before examining this in detail, it needs to be noted that an additional argument by him refers to the entry for the term anāgāmin in the Pāli-English dictionary, Rhys Davids and Stede $1921 / 1993$, p. 31, reasoning that this testifies to "an earlier non-technical use of the word "Anāgāmin." This argument appears to be based on a misunderstanding of this entry, which only reports that some passages refer to the nonreturner without explicitly mentioning the fetters. This is entirely natural, as they instead describe the practices or qualities required for reaching this level of awakening.

Turning to the Sämaññaphala-sutta (DN 2), this discourse reports the Buddha providing an account of the gradual path to a king who had inquired about the fruits to be expected from going forth. One of several parallels to the Sämaññaphalasutta, extant in the Ekottarika-ägama, does not mention the gradual path at all (EĀ 43.7). This leaves open the possibility that the gradual path account was not from the outset an integral part of this particular discourse.

In the Digha-nikayya, an account of the gradual path is given in full in the Sämaññaphala-sutta and then abbreviated in subsequent discourses. The Chinese Dirrgha-ägama 
counterpart to the Sämañnaphala-sutta, however, only present the gradual path in abbreviation (DA 27$)$. The order of discourses in this collection differs, wherefore the full account occurs in a previous discourse in this collection. This exemplifies the fact that the description of the gradual path in the collections of long discourses is not specific to the narrative setting of the Sämaññaphala-sutta (or its parallels). Instead, it is a formulaic passage used again and again to provide an overview of the Buddhist path of practice to various outsiders.

Moreover, a comparative study of gradual path descriptions in the early discourses shows that variations in coverage occur even among discourses of the same reciter tradition (Anālayo 2016). This shows that such descriptions were not invariably meant to provide exhaustive accounts of all practices and attainments.

Confirmation for this assessment can be found in the Sāmaññaphala-sutta and its parallels, according to whose concluding section the Buddha told his disciples that the king could have reached the stage of stream-entry on hearing this discourse, had he not been a patricide. Most of the parallel versions refer to this potential in terms of the arising of the Dharma eye (DN 2: virajam vitamalam dhammacakkhum uppajjissatha, DĀ 27: 得法眼淨, and T 22: 遠塵離垢, 諸法眼 生, with the difference that in the version mentioned last this is not just a potential but something that actually happened). Alternative formulations speak of penetrative insight into the four noble truths (Gnoli 1978, p. 252: catvāri āryasatyāny abhisamitāny abhavișan) or mention that he became one of the four pairs and eight persons (EĀ 43.7: 在四雙八輩之中), a standard reference to those on the path to and those who have attained the four levels of awakening (on distinct perspectives regarding the temporal duration of these paths in early and later tradition see Anālayo 2014, p. 144).

In spite of employing different formulations, the parallels testify to knowledge of the first of the four stages of awakening, even though this has not been explicitly included in their respective versions of the gradual path account (if they provide such an account.) This shows that the lack of reference to the lower three of the four stages of awakening in those gradual path accounts is best understood as an intentional choice rather than as testifying to their supposedly late nature. As already mentioned, it is a category mistake to assume that, since later exegesis strives to give a comprehensive coverage of a particular topic, the same must hold for the early discourses. The assumption that the account of the gradual path in the Sāmaññaphala-sutta must cover all four levels of awakening is a good example for such a category mistake.

Another argument raised by Nanda $(2019$, p. 223$)$ is that none of the records of the Buddha's awakening "present any indication of the Buddha going through the four stages," the same also being the case for reports of disciples who become arahants. However, the early Buddhist doctrine of four levels of awakening does not imply that everyone must attain these one after the other. Someone with a high degree of maturity of the five spiritual faculties (indriya/根/dbang po) can proceed straight through to full awakening. The discourses in fact explicitly indicate that the degree of maturation of the five spiritual faculties expresses itself in which of the four levels of awakening will be attained (SN 48.14 and SĀ 652).

References to these four levels of awakening often take the form of an eightfold listing, which mentions those on the path to any of the four levels alongside those who have attained them. Sometimes the order of such eightfold listings appears to have suffered from transmission errors (Anālayo 2012). The standard Pāli phrase introducing such listings is cattâri purisayugāni atțha purisapuggalā (e.g. MN 7) which has a counterpart in 四雙八輩 (in the parallel EA 13.5 and the otherwise unrelated $\mathrm{DA} \overline{2}, \mathrm{MA}$ 128, and $\mathrm{SA}$ 931); alternative expressions convey the same sense, such as 四雙人八輩 $(M \bar{A}$ 202) or 四雙八士 (SĀ 550). Often such references are followed by explicit listings of the four paths and fruits. These occur not only in the Pāli discourses of the Theravāda reciter tradition but also in discourses from each of the four Chinese $\bar{A}$ gamas, probably representing Dharmaguptaka, Sarvāstivāda, Mūlasarvāstivāda, and perhaps Mahāsānghika reciter traditions. Once comparative study shows that different reciter lineages agree on a particular doctrine, this reflects "early Buddhist thought" to the extent to which we are still able to reconstruct it nowadays. In other words, from a comparative perspective the idea of four levels of awakening emerges as an integral dimension of early Buddhist thought.

\section{Stream-entry}

Regarding the first of the four levels of awakening, Masefield (1986/1987, p. 134) argued that the term sotäpanna does not refer to a "stream-enterer," as according to his assessment it means "rather "one who has come into contact with (or undergone) the hearing." "This suggestion is based on the ambiguity of the Pāli term sota (or of its Sanskrit equivalent śrota), which can mean "stream" but also "the organ of hearing." The proposed reasoning overlooks the fact that the Pāli term for receiving teachings by hearing is sotānugata rather than sotāpanna (AN 4.191). It also does not take into account that a Pāli discourse (in agreement with its parallel) offers a definition of sota in the context of a discussion of aspects of streamentry, which clearly shows the relevant meaning to be the "stream":

The noble eightfold path is the stream.

(SN 55.5: ariyo ațthangiko maggo soto).

What has been spoken of by the Blessed One as "the stream," this is reckoned to be the noble eightfold path. (SĀ 843: 世尊所說流者, 謂八聖道). 
Manné (1995, p. 66) saw a problem in the above definition of the stream as the eightfold path, as it implies that the stream-enterer is endowed with the eightfold path. According to her assessment, this "is a problem because a classical aspect of the attainments of the Arahat is that he has completely followed and fully achieved the path leading to the extinction of the āsavās [influxes], which is precisely this Noble Eightfold Path."

This suggestion does not give due recognition to the fact that the cultivation of the eightfold path is relevant to various levels of awakening, and that each of its eight factors can be developed to differing degrees. Moreover, with the attainment of full awakening, the arahant is considered to be endowed with a tenfold path (e.g., MN 117 and its parallels MĀ 189 and Up 6080), which comprises right knowledge and right liberation in addition to the eight factors of the path. Being endowed with the tenfold path is unique to the arahant, unlike the eightfold path.

Manné (p. 87) also argued that the phrase designating that someone is on the path to the realization of stream-entry, "sotāpattiphalasacchikiriyāya pațipannno, may be construed to qualify the term sotapanno," the stream-enterer. This then led her to the conclusion that it "makes sense that if one has attained something, one will, by definition, enjoy its fruit," hence it follows that "the division into stage and fruit is spurious." Yet, to be on the path to a certain goal does not mean that one must have already reached the final destination of that path. As already noted by Harvey (1993, p. 10 n. 23), the above-mentioned argument "fails to see that a patipanna [being on the path] person is one who is still practicing to attain the relevant fruit." In other words, the distinction between being on a particular path and reaching its final destination is not spurious, and this holds for the path to a mundane goal just as for the path to a level of awakening.

Manné (1995, p. 48) also reasoned that "usually the disappearance of the three fetters is presented as the characteristic of the sotāpanna [stream-enterer], and this attainment coupled with the reduction of rāga, dosa and moha [lust, anger, and delusion] is presented as the characteristic of the sakadaggamin [once-returner]," hence this "points to a time when these two attainments were not yet clearly differentiated into separate and discrete stages of attainment." In support of the position taken by Manné, Nanda (2019, p. 237) additionally argued that "stream-enterers also attenuate greed, hatred and delusion," since "it is difficult to concede that any spiritual progress could be possible without attenuating the three." In particular the eradication of the first fetter of identity belief "theoretically reduces a great extent of delusion, greed, and hatred."

The indication in the discourses that a once-returner has substantially diminished the three root poisons in the mind is found similarly in parallel versions representing different transmission lineages, as evident from the discourse that compares the Buddha to a cowherd, translated above. It does not imply that a stream-enterer does not diminish these three root poisons at all. The point is simply that the most salient characteristic of stream-entry is the disappearance of the three fetters, whereas the most salient characteristic of once-return is a substantial diminishing of the three root poisons.

The discourses regularly describe the "limbs of stream-entry" as qualities characteristic of a stream-enterer. These are experiential confidence (aveccapasāda) in the Buddha, his teaching, and the community of disciples at various levels of awakening, often combined with the quality of having a firm commitment to moral conduct. Masefield (1986/1987, p. 131) proposed a distinction between the acquisition of the limbs of stream-entry and the actual attainment of stream-entry, supposedly evident in the example of Anāthapindika who, although endowed with the limbs of stream-entry, only reached the actual attainment of stream-entry when on his deathbed (the reference is to MN 143, which has parallels in SA 1032 and $E \bar{A}$ 51.8). However, none of the extant versions of this discourse reports that Anāthapindika attained stream-entry at that time. Instead, tradition associates his attainment of stream-entry with his first encounter with the Buddha, long before he passed away (Anālayo 2010). This exemplifies the fact that the relationship between the attainment of streamentry and the limbs of stream-entry is the inverse of the above-mentioned proposal. The acquisition of these limbs results from the attainment of stream-entry.

The same perspective also helps to correct the assumption by Nanda (2017, p. 24) that the four limbs of stream-entry are "necessary preconditions for establishing the stage of streamentry." Instead, it is because of having already and personally experienced the first level of awakening with stream-entry that the stream-enterer will be endowed with experiential confidence that the Buddha had indeed reached awakening, that the Buddha's teaching indeed leads to awakening, and that the community of the Buddha's practicing disciples is indeed on the path to awakening.

Understood in this way, the tendency in the early discourses to highlight such firm confidence, together with firm ethical conduct, reflects the importance accorded to the personal transformation to be expected from the gaining of stream-entry. Such personal transformation offers a way of self-evaluation more reliable than any subjective experience that one may have had, be this in formal meditation or apart from it. The early discourses clearly distinguish the confidence that results from stream-entry from confidence in general. They qualify the former by using specific terminology, here rendered as "experiential confidence": Pāli aveccapasāda, Sanskrit avetyaprasāda, Chinese 不壞淨, Tibetan shes nas dad pa. Cone (2001, p. 259) explained that the Pāli term avecca conveys "understanding, having penetrated," hence in her words the phrase aveccappasāda conveys the idea of a "trust founded in knowledge." This differs 
from just having gained confidence or faith by way of conversion to the Buddhist tradition, for which the early discourses use a different term: Pāli saddhā, Sanskrit śraddhā, Chinese 信, Tibetan dad pa.

The clear terminological distinction drawn in this way has apparently been overlooked by Manné (1995, p. 57), who considered descriptions of the endowments of a streamenterer to be simply mentioning "the qualities that any religion would require of its followers," an assessment that then led her to perceive a "general blithe tendency to open the stage of sotāpanna [stream-enterer] to all and sundry through simplifying the required attainment to that of faith alone" (p. 62). This assumption then led her to propose that stream-entry "was originally the stage, or perhaps more accurately the state of convert. The sotapanna was originally no more and no less that [sic] someone who had converted to Buddhism" (p. 94). The proposed conclusion fails to do justice to the textual evidence.

\section{The Higher Levels of Awakening}

Some scholars have proposed that becoming an arahant features in the early texts as the sole reserve of monastics (e.g., Hwang 2006, p. 34, Lamotte 1952, p. 388, and Nanda 2019, p. 240). Others instead have asserted that discourses in the Anguttara-nikāya (AN 6.119 and 6.120) prove the existence of lay arahants (e.g., Bluck 2002, p. 10, Dutt 1957, p. 145, Harvey 1990, p. 218, Samuels 1999, p. 238, Schumann 1982/ 1999 , p. 217, and Somaratne 2009, p. 153). Both positions do not reflect the perspective of the texts accurately. The Anguttara-nikāya passages in question list several lay disciples who are endowed with six qualities, which include the four limbs of stream-entry. The passages then state that each of these lay disciples "has come to certainty in relation to the thus-gone one, is a seer of the deathless, and proceeds having realized the deathless" (tathāgate nitthangato amataddaso amatam sacchikatvā iriyati). Several of the lay disciples mentioned in this passage are on record elsewhere for being still at a lower level of awakening when passing away (Anālayo 2010). A case in point is Anāthapindika, already mentioned above. This shows that the reference to a realization of the deathless, Nirvana, intends something that happens before becoming an arahant. It refers to something already experienced with the attainment of stream-entry.

On the other hand, it also does not follow that lay practitioners can in principle never reach the highest level of awakening. But reported cases of such attainment in the early discourses invariably indicate that the one who has now become an arahant goes forth and lives as a monastic, unless death intervenes. In sum, the passage in question has no direct implication for the attainment of arahant-ship. What it does clarify is rather that stream-entry already involves an experience of the deathless.

This clarification helps to put into perspective a suggestion by Sirimane (2016, p. 164) that "a stream-enterer understands Nibbāna only through anvaye ñanna (knowledge by entailment)," as "Nibbāna has not been fully experienced even by a trainee (sekha). A stream-enterer can also only 'deduce' it" (p. 199). Instead, as the above-quoted passage shows, streamenterers have already had a direct experience of Nirvana, and it is this experience that results in the breaking of the three fetters and in establishing them in the limbs of stream-entry.

Regarding the eventual attainment of the highest level of awakening, Horner (1934, p. 796) proposed that "the arahan was regarded as having some bourn beyond, when this life was over." This proposal is based on her assumption (p. 786), in relation to the Buddha, that "a great teacher would not have seen perfection as realisable under physical conditions: he would have thought of man growing up to perfection as he ran on and fared on, his thought, word and deed becoming finer and purer in each new rebirth." Moreover, according to her assessment (p. 789), the "ocean of samsāra (rebirths) had originally been regarded as a thing full of the promise of infinite opportunities for progress."

As already noted by Bond (1984, p. 236), this presentation involves "a misinterpretation stemming from false presuppositions imposed on the material." The textual records point to the exact opposite of such a position, namely a consideration of samsāra as something to be transcended and of arahants as having definitely achieved this when they attained full awakening, which implies that they were beyond any further rebirth.

Manné (1995, p. 85) voiced the impression that "at a certain point in the history of Buddhism there was a confusion between the stages of Arahat and anāgāmin [nonreturner], and a problem in separating them." This suggestion is based on the indication that one will become only a non-returner instead of an arahant if one still has a remainder of clinging. An example in case occurs in the Satipațthāna-sutta and its Madhyama-āgama parallel (not found in a third parallel in the Ekottarika-āgama), which describe the results to be expected from proper practice of the four establishments of mindfulness (this is also another instance showing that a reference to "here and now" only functions as an alternative option, as discussed above). The descriptions take the following form:

either final knowledge here and now or, if there is a trace of clinging left, non-returning.

(MN 10: dițthe va dhamme añ̃̄an, sati vā upādisese anāgāmitā).

either final knowledge here and now or, if there is a remainder [of clinging], the attainment of non-returning. ( $M \bar{A}$ 98: 或現法得究竟智, 或有餘得阿那含). 
The problem, according to Manné (p. 86), is that such passages give "no information regarding the condition under which a remainder would exist, and thus no explanation why one stage rather than another should be attained." It is not clear what additional specifications and explanations should be required. The main point is simply to clarify that even a trace of clinging will prevent whole-hearted practice of the four establishments of mindfulness from issuing in the attainment of the final goal. This seems clear enough, and no further details would be required for this qualification to separate the two levels of awakening in question and for clarifying what reaching the higher of the two requires, namely the total removal of any form of clinging.

Needless to say, this presentation does not imply that the practice described in the Satipațthāna-sutta and its Madhyama-āgama parallel could not issue in stream-entry or once-return. These are best understood to be implied in the reference to non-return and full awakening, whose explicit mention seems to serve to highlight the potential of a cultivation of the four establishments of mindfulness to result in a complete purification of the mind from the root defilements of lust and anger, which according to the early Buddhist analysis are the chief culprits for a broad range of troubles and miseries.

\section{Compliance With Ethical Standards}

Ethical Approval This article does not contain any studies performed by the author with human participants or animals.

Conflict of Interest The author declares that he has no conflict of interest.

Abbreviations AN, Añguttara-nikāya; DĀ, Dīrgha-āgama (T 1); DN, Dīgha-nikāya; EĀ, Ekottarika-āgama (T 125); MĀ, Madhyama-āgama (T 26); MN, Majjhima-nikāya; SĀ, Samyukta-āgama (T 99); SN, Samyutta-nikāya; T, Taishō edition; Up, Abhidharmakośopāyikā-țīkā

Open Access This article is licensed under a Creative Commons Attribution 4.0 International License, which permits use, sharing, adaptation, distribution and reproduction in any medium or format, as long as you give appropriate credit to the original author(s) and the source, provide a link to the Creative Commons licence, and indicate if changes were made. The images or other third party material in this article are included in the article's Creative Commons licence, unless indicated otherwise in a credit line to the material. If material is not included in the article's Creative Commons licence and your intended use is not permitted by statutory regulation or exceeds the permitted use, you will need to obtain permission directly from the copyright holder. To view a copy of this licence, visit http://creativecommons.org/licenses/by/4.0/.

\section{References}

Amaro, A. (2019). Unshakeable well-Being: is the Buddhist Concept of enlightenment a meaningful possibility in the current age. Mindfulness, 10, 1952-1956. https://doi.org/10.1007/s12671-01901179-7.
Anālayo, Bh. (2010). Teachings to lay disciples: the Samyukta-āgama parallel to the Anāthapiṇ̦ikovāda-sutta. Buddhist Studies Review, 27(1), 3-14. https://doi.org/10.1558/bsrv.v27i1.3.

Anālayo, Bh. (2011). A comparative study of the Majjhima-nikāya. Taipei: Dharma Drum Publishing Corporation.

Anālayo, Bh. (2012). Purification in early Buddhist discourse and Buddhist ethics. Bukkyō Kenkyū, 40, 67-97.

Anālayo, Bh. (2013). Awakening. In A. L. C. Runehov \& L. Oviedo (Eds.), Encyclopedia of Sciences and Religions (pp. 183-185). Dordrecht: Springer.

Anālayo, Bh. (2014). The dawn of Abhidharma. Hamburg: Hamburg University Press.

Anālayo, Bh. (2016). The gradual path of training in the Dīrgha-āgama, from sense-restraint to imperturbability. Indian International Journal of Buddhist Studies, 17, 1-24.

Anālayo, Bh. (2018). Rebirth in early Buddhism and current research. Boston: Wisdom Publications.

Anālayo, Bh. (2021). The qualities pertinent to awakening: bringing mindfulness home. Mindfulness. https://doi.org/10.1007/s12671020-01398-3.

Bluck, R. (2002). The path of the householder: Buddhist lay disciples in the Pāli canon. Buddhist Studies Review, 19(1), 1-18.

Bond, G. D. (1984). The development and elaboration of the arahant ideal in the Theravada Buddhist tradition. Journal of the American Academy of Religion, 52(2), 227-242.

Cohen, R. S. (2006). Beyond enlightenment, Buddhism, religion, modernity. London: Routledge.

Cohen, E. (2010). From the Bodhi tree, to the analyst's couch, then into the MRI scanner: the psychologisation of Buddhism. Annual Review of Critical Psychology, 8, 97-119.

Cone, M. (2001). A dictionary of Pāli, part I, a-kh. Oxford: Pali Text Society.

Dutt, S. (1957). The Buddha and five after-centuries. London: Luzac.

Gimello, R. M. (2004). Bodhi (Awakening). In R. E. Buswell (Ed.), Encyclopedia of Buddhism (pp. 50-53). New York: Macmillan.

Gnoli, R. (1978). The Gilgit manuscript of the Saighabhedavastu, being the 17th and last section of the Vinaya of the Mülasarvāstivädin. Rome: Istituto Italiano per il Medio ed Estremo Oriente.

Harvey, P. (1990). An introduction to Buddhism: teachings, history and practices. Delhi: Munshiram Manoharlal.

Harvey, P. (1993). The sangha of noble sāvakas, with particular reference to their trainee member, the person 'practising for the realization of the stream-entry-fruit'. Buddhist Studies Review, 30(1), 3-70. https://doi.org/10.1558/bsrv.v30i1.3.

Horner, I. B. (1934). The four ways and the four fruits in Pāli Buddhism. Indian Historical Quarterly, 10, 785-796.

Hwang, S. (2006). Metaphor and literalism in Buddhism, the doctrinal history of nirvana. London: Routledge.

Lamotte, É. (1952). La bienveillance bouddhique. Bulletin de la Classe des Lettres et des Sciences Morales et Politiques de l'Académie Royale de Belgique, 38, 381-403.

Manné, J. (1995). Case histories from the Pāli canon, II: sotāpanna, sakadāgāmin, anāgāmin, arahat - the four stages case history or spiritual materialism and the need for tangible results. Journal of the Pali Text Society, 21, 35-128.

Masefield, P. (1986/1987). Divine revelation in Pali Buddhism. Colombo: Sri Lanka Institute of Traditional Studies.

McMahan, D. L. (2008). The making of Buddhist modernism. New York: Oxford University Press.

Nanda, A. (2017). The concept of stream-enterer in Pāli literature. Anveșanāa, 8, 22-49.

Nanda, A. (2019). Origins of the theory of four stages to arahantship in Theravāda soteriology. Indian International Journal of Buddhist Studies, 20, 219-256. 
Norman, K. R. (1990). Aspects of early Buddhism. In D. S. Ruegg \& L. Schmithausen (Eds.), Earliest Buddhism and Madhyamaka (pp. 24 35). Leiden: Brill.

Pande, G. C. (1957). Studies in the origins of Buddhism. Department of Ancient History, Culture and Archaeology: University of Allahabad.

Rhys Davids, T. W., \& Stede, W. (1921/1993). Pali-English Dictionary. Delhi: Motilal Banarsidass.

Samuels, J. (1999). Views of householders and lay disciples in the Sutta Pițaka: a reconsideration of the lay/monastic opposition. Religion, $29,231-241$.

Schumann, H. W. (1982/1999). Der historische Budddha, Leben und Lehre des Gotama. München: Diederichs.

Sirimane, Y. (2016). Entering the stream to enlightenment, experiences of the stages of the Buddhist path in contemporary Sri Lanka. Sheffield: Equinox Publishing.
Somaratne, G. A. (2009). White-clothed celibate Arahants in early Buddhism. In K. L. Dhammajoti \& Y. Karunadasa (Eds.), Buddhist and Pali studies in honour of the venerable Professor Kakkapalliye Anuruddha (pp. 151-167). Hong Kong: Centre of Buddhist Studies, University of Hong Kong. Stache-Rosen, V. (1968). Dogmatische Begriffsreihen im älteren Buddhismus II; das Sañgittisūtra und sein Kommentar Sañititiparyāya. Berlin: Akademie Verlag.

Vaudeville, C. (1975). The cowherd god in ancient India. In L. S. Leshnik et al. (Eds.), Pastoralists and Nomads in South Asia (pp. 92-116). Wiesbaden: Otto Harrassowitz.

Publisher's Note Springer Nature remains neutral with regard to jurisdictional claims in published maps and institutional affiliations. 